Even allowing that Berger's estimate is made higher by inflation, as Hill explains, country foods must have weighed as heavily as wages in the northern mixed economy of the 1970s. It is likely they still do. I began by showing that, 'Given proper institutional support, a mixed economy should persist into the next century'. I noted, moreover, that 'Critics of the bush economy have underestimated its contribution to the welfare of Northern natives' (Cox 1985: 393). I have no wish to revise either statement.

\title{
FLORENCE, FRANCIS ALLYN AND TELEFON
}

\author{
HENRY R. HEYBURN \\ Brown, Todd and Heyburn, 16th floor, Citizens Plaza \\ Louisville, KY 40202 USA
}

Received September 1985

I read with great interest the article by Messrs $R$. K. Headland and P. L. Keage in the May 1985 issue of Polar Record about King George Island. I was particularly interested in references to the over-wintering by $\mathrm{Mr} \mathrm{King}$, the mate of the Florence. I came across the same reference in the article 'Antarctica', by Edwin Swift Balch, in the fournal of the Franklin Institute, February 1904, and have spent many hours trying to piece together further details.

According to the Whalemens' Shipping List, the rescue vessel Francis Allyn sailed from New London 28 August 1877 for 'Desolation Island' (Iles Kergulen) and did not return to New London until 13 May 1879, that is, after the passage of two Antarctic summers. If she rescued King during the summer of $1877-78$, the question arises as to whether she went first to Kergulen. Despite intensive search I have not found the logs of either Florence or Francis Allyn for these crucial voyages, nor any accounts in the New London newspapers of the return to home port, which I thought might have been cause for a story. Moreover, attempts to find crew lists of these two boats, with King's name deleted or added, have been unsuccessful.

Apparently Balch's source of information was Captain Thomas B. Lynch of Peace Dale, Rhode Island, who sailed from Stonington, Connecticut in 1879 in the Express, in an unsuccessful search for the Charles Shearer. During this voyage he saw the remains of King's boat-hut on King George Island. Balch says that at that time (1904) Captain Lynch still had the Express log from that voyage, but my attempts to find the log have hit a blank wall. Somewhere out there must be the logs, diaries, contemporary newspaper accounts or court records that will fill in details of this intriguing story.

I was interested also in Headland and Keage's note on the wreck and salvage (not sinking) of Telefon. The best account I know is in Charcot's Voyage of the Why Not?. This was a collier of 4,000 tons which, in bringing fresh stocks of coal to the whalers in Admiralty Bay, became stranded on rocks at the entrance to the bay in late December 1908. Telefon was abandoned by her crew, who reached the whaling station in boats. On hearing of the stranding, all the little whale-boats at Deception Island raced for Admiralty Bay. The Almirante Valenzuela shot ahead, and Captain Andresen leapt on board Telefon and hoisted his flag. Since the ship had been totally abandoned she was 
considered his fair prize. With great difficulty Andresen got her off the rocks and back to Deception Island, where he beached her opposite Pendulum Cove.

Andresen returned early the following year. Charcot reported that the injuries to the hull were tremendous but, with the help of a diver and crew of six, Andresen refloated Telefon, plugging her holes with cement, and sailed her back to South America. In 1910 Charcot was pleased to see a fully-refurbished Telefon plying between Deception and Punta Arenas under Andresen's command. Telefon Rocks off Admiralty Bay, and Telefon Bay at the northern end of Port Foster, Deception Island, are named after the vessel. Any further information on the wreck and salvaging of Telefon will be greatly appreciated.

\section{Reviews}

\section{THE USA AND THE ARCTIC}

US ARCTIC INTERESTS: THE 1980s AND 1990s. Westmeyer, W. E. and Shusterich, K. M. (editors). 1984. New York, Springer-Verlag. 369 p, illustrated, hard cover. ISBN 30540-96009-0. app DM 85, US\$33.00.

This volume sets forth, in a collection of 16 essays, issues relating to United States interests in the Arctic. Contributors include representatives of industry, environmental advocates, native groups, government and academics. Some of the material is repetitive, but this helps to underscore the key issues as seen from different viewpoints. Resource exploitation, its effects, and related issues of jurisdiction and policy-making are the main themes of the collection. One essay is devoted to military security issues.

William E. Westermeyer, one of the editors, sets the stage by discussing the range of US interests in the Arctic. These include national security, energy development, relations with the State of Alaska, international relations, living resources, environmental protection, science, and the welfare of indigenous peoples. He points out that the many federal agencies with responsiblities in the Arctic 'will occasionally get in one another's way,' and suggests that there be some degree of coordination of activities within the framework of an 'authority', which would have the ability to resolve disputes among competing interests.

- John A. Dugger writes of policy-making with respect to oil and gas development ("the major resources'), discussing first the unique characteristics of the Arctic, then the sources of policy. He cites the problem of exporting Alaskan oil to Japan, seeing the federal government as neutral and following a laissez faire policy with respect to arctic development. With prospects for increased demand for resources and the high costs of development, he sees a need for an Arctic Development Authority and governmentindustry coordination.

John N. Garrett's nuts-and-bolts industrial appraisal of crude oil production represents arctic Alaska as an extremely promising hunting ground for future US oil. Garrett pleads the industry's case for favourable tax laws and relief from a complicated regulatory system. He wants to mitigate economic risks associated with development, to encourage industry's eagerness and willingness to continue exploration. Thomas P. Miller discusses hard minerals, secondary to oil in economic importance, and unlikely to be developed further before the end of the century. Westermeyer provides a second essay on the economic, 